\title{
EFFECT OF PHYSICAL AND CHEMICAL TREATMENTS ON BERSEEM SILAGE QUALITY, NUTRITIVE VALUES, RUMEN FERMENTATION AND BLOOD METABOLITES OF RAMS Abd El-Hady, M. A. A. ${ }^{1}$; A. A. Gabr ${ }^{2}$; S. A. El-Ayouty ${ }^{2}$ and M. A. Z. Shahin ${ }^{2}$ \\ ${ }^{1}$ Animal Production Res. Inst., Agric. Res. Center, Dokki, Giza, Egypt. \\ ${ }^{2}$ Animal Production Dept., Fac. Agric., Mans. Univ., Egypt. \\ E-mail: magid_70@hotmail.com
}

\begin{abstract}
The object of this study was to investigate the effect of wilting, chopping and formic acid treatment on berseem silage quality besides determination of digestibility, rumen fermentation and blood metabolites of rams fed tested rations. Berseem forage (at $3^{\text {rd }}$ cut) was manually chopped at $2-3 \mathrm{~cm}$ of length and wilted for 0,24 or $48 \mathrm{hr}$ and thereafter ensiled with or without formic acid $(0.5 \%)$ treatment in plastic barrels. At the same time, another quantity of un-chopped berseem forage was wilted for $24 \mathrm{hr}$ and ensiled with or without formic acid treatment. Digestibility trials were conducted to evaluate the utilization of berseem silages using mature Ossimi rams. The results showed that DM of berseem silage increased by wilting to around $20 \%$ and $30 \%$ for $24 \mathrm{hr}$ and $48 \mathrm{hr}$, respectively. The wilted silage for $24 \mathrm{hr}$ and treated with formic acid (S4) had the lowest value of $\mathrm{pH}$ (being 3.87), the highest level of lactic acid $(3.15 \%)$ the lowest level of acetic (1.57\%) and butyric acids (0.0\%) with Flieg's score 90 . The lowest level of lactate and Flieg's score of quality, whilst the highest $\mathrm{pH}$ value was obtained in un-chopped berseem silage either treated or untreated with formic acid. Likewise, the highest count of lactobacilli, the lowest mold and clostridia were found in S4, which were positive correlated with fermentation parameters. Digestibility of DM, $\mathrm{OM}, \mathrm{CP}, \mathrm{EE}$ and $\mathrm{CF}$ was higher $(\mathrm{P}<0.01)$ in un-wilted than wilted silages, as well as, nutritive values had a similar trend. The intake of TDN, DCP and ME was higher $(\mathrm{P}<0.05)$ in wilted silage rations than un-wilted. Formic acid treatment improved $(P<0.05)$ digestibility of most nutrients, whilst nutritive values did not differ significantly. The nutrients digestibility of un-chopped silage was lower than chopped silage except for CF and its fractions. The quality index $(\mathrm{QI})$ value was $(P<0.05)$ improved by wilting of silage. The lowest value of QI was found in un-chopped and unwilted silages. Rumen liquor parameters were not significantly affected by wilting or formic acid treatment, except for NH3-N and TVFA's which were higher in wilted than un-wilted silage. The highest $(\mathrm{P}<0.01)$ value of $\mathrm{NH} 3-\mathrm{N}$ and TVFA's was showed in wilted for $24 \mathrm{hr}$ and treated silage. The $\mathrm{pH}$, eNDF and $\mathrm{NH}_{3}-\mathrm{N}$ values were higher in un-chopped than chopped silage ration. Blood hemoglobin and hematocrite values, as well as plasma total protein and glucose $(P<0.01)$ increased in wilted silage groups than un-wilted. Whereas, formic acid did not affect blood parameters. It could be concluded that, the lowest quality and digestibility was obtained with un-chopped silage either with or without formic acid treatment. Chopping and wilting berseem forage for $24 \mathrm{hr}$ (about $20 \% \mathrm{DM}$ ) as pre-ensiled treatments with formic acid sprinkle produced the best quality silage and higher digestibility without any side effect on health of rams during the experimental period, which could be resulted in improvement growth performance of the animal.
\end{abstract}

Keywords: Berseem, silage, wilting, chopping, formic acid, digestibility, fermentation, rams. 
Abd El-Hady, M. A. A. et al.

\section{INTRODUCTION}

There is a great shortage in animal feedstuffs in Egypt especially throughout summer period which reflects on the productions of such animals (Shalaby et al., 1989). Whereas, in winter season berseem clover (Trifolium alexandrinum) is the main forage as an annual malti-cut crop fed ad libitum as a common practice. This species has the advantage over other annual species of providing multiple harvests and high protein yield during the growing season. Some of this forage is dried in last cut to produce berseem hay for summer feeding, but the amount of hay is not enough and loss some of nutritive value and carotenoids. Therefore, silage making of berseem that is plentiful during the wet season is one of the solutions to feed shortages in the summer season (Khan et al., 2006). Ensiling forages has several advantages relative to harvesting as hay. These include greater opportunity for mechanization, reduce labor cost and less chance of weather losses (Mustafa and Seguin, 2003). Unfortunately, ensiling berseem is not widespread in Egypt because of many problems affect silage quality. Where, leguminous fodders have high buffering capacity due to high moisture, minerals and protein contents, therefore $\mathrm{pH}$ drops slowly during ensiling and resulted in high nutrient losses (Bolsen et al., 1996). Ensiling high moisture crops could result in clostridia fermentation that led to heavy loss of nutrients (Gary, 1992 and Matsuoka et al. 1993). Therefore, before ensiling lucerne or berseem fodder, moisture contents should be reduced either by field wilting or by the addition of some absorbent (Touqir et al., 2007). Time of wilting has been investigated and produced extremely variable results due to weather conditions such as humidity, wind speed and ambient temperature prevailing at the time of the trial (McDonald et al., 1991). Biochemical losses from respiration could be higher than losses from un-wilted silage and digestibility of the silage is reduced (Thomas and Thomas, 1985). Several workers reported that the optimum level of wilting was to arrive $20-30 \%$ DM of pre-ensiling forage (McDonald et al., 1991; Suepea et al., 2000; Touqir et al., 2007).

The main goal of silage making is to preserve as much of the nutritional value of the original crop as possible. Preservation is achieved by acidity and by maintaining an oxygen-free (anaerobic) environment. Acids are produced by bacteria that convert fermentable carbohydrates into organic acids, predominantly lactic and acetic acids. Formic acid is widely used to accomplish this target and direct rapid $\mathrm{pH}$ drop of ensiled material and eventually the acidity level is adequate to inhibit or kill most bacteria and other microorganisms and consequently nutrient losses. At this $\mathrm{pH}$ if protected from exposure to air and water seepage, silage can be preserved for a long period (Tauqir et al., 2008). Addition of formic acid to silage material has been reported to have generally positive effects on fermentation (Haigh, 1988 and Snyman et al., 1996). Fairbairn et al. (1992) found that the application of $4.5 \mathrm{~L}$ formic acid/ton fresh matter reduced proteolysis in alfalfa owing to rapid reducing $\mathrm{pH}$. As well as, chopping of pre-ensiling forage is one of the main important factors affects silage fermentation and therefore its quality 
(Woolford, 1984). It can lead to rapid fermentation, therefore fall in $\mathrm{pH}$ of forage. The chopping of ensiling forage increases silage intake in two ways: firstly, through improving the fermentation quality and, secondly, through increasing the rate of passage of food through the rumen, therefore the rumination is easier than in un-chopped silage (McDonald et al., 1991).

In Egypt, the majority of silage is made from corn only, as a summer crop. Whereas, ensiling berseem forage as a winter crop is not wide due to lower quality and preservation, as well as the local previous studies on ensiling berseem was done as a whole plant without chopping. The question of this study was: how can be improved berseem silage quality and preservation? Therefore, the main object of this study was to investigate the effect of wilting and chopping as a pre-ensiling physical process with or without formic acid treatment on berseem silage quality, digestibility, rumen fermentation and blood constituents with sheep.

\section{MATERIALS AND METHODS}

This study was conducted at the Experimental Farm of the Animal Production Department, Faculty of Agriculture, Mansoura University. The analytical work was undertaken at the laboratories of department. The experimental groups were distributed as following:

1) S1: Berseem was ensiled without wilting or formic supplement.

2) S2: Berseem was ensiled without wilting but sprinkled with $0.5 \%$ formic acid.

3) S3: Berseem was ensiled after wilting for $24 \mathrm{hr}$ without formic supplement.

4) S4: Berseem was ensiled after wilting for $24 \mathrm{hr}$ and sprinkled with $0.5 \%$ formic acid.

5) S5: Berseem was ensiled after wilting for $48 \mathrm{hr}$ without formic supplement.

6) S6: Berseem was ensiled after wilting for $48 \mathrm{hr}$ and sprinkled with $0.5 \%$ formic acid.

7) S7: Berseem was ensiled after wilting for $24 \mathrm{hr}$ as whole plants without chopping or formic supplement.

8) S8: Berseem was ensiled after wilting $24 \mathrm{hr}$ as whole plants without

\section{Ensiling process:} chopping and sprinkled with $0.5 \%$ formic acid.

About 2 ton of $3^{\text {rd }}$ cut fresh berseem (Trifolium alexandrinum L.) was collected from the field and divided into 8 equal portions for making silages with different treatments as above. The chopping process was carried out manually by knifes (2-3 cm of length) and wilted for 0 (15\% DM), $24 \mathrm{hr}$ $(18.7 \% \mathrm{DM})$ or $48 \mathrm{hr}(28 \% \mathrm{DM})$ in sunny days during April, 2007. The unchopped berseem was wilted for $24 \mathrm{hr}$ and contained 21.8\% DM. Berseem was well pressed manually by legs (to ensure air removal) in plastic barrels (200 liter) with or without sprayed formic acid (0.5\% as fresh matter). Formic acid was diluted with little of water and sprayed every $20 \mathrm{~cm}$ layers of berseem. After full filling of each barrel, it was covered by plastic sheet and 
Abd El-Hady, M. A. A. et al.

packed by barrel covers and belt to maintain anaerobic condition of silo. All barrels were kept at room temperature for 2 months before feeding animals.

Evaluation of silage quality:

For judging the quality of berseem silage, physical characteristics like color, odder and smell of silages were examined. Samples of each silo were taken when opened for subsequent proximate chemical analysis, as well as fermentation characteristics of silage were examined. Silage extract was prepared by homogenizing $20 \mathrm{~g}$ wet material of each sample with $100 \mathrm{ml}$ distilled water in warm blender for 10 min. (Waldo and Schultz, 1956). The homogenized samples were filtered through double layer of cheese cloth and filter paper. Then, the filtrate was used to determine silage $\mathrm{pH}$ directly by digital $\mathrm{pH}$-meter with a combined electrode. Lactic acid was determined in silage juice spectrophotometry according to Barker and Summerson, (1941). Determination of acetic, propionic and butyric acid concentrations were measured chromatography according to Jayaprakasha et al. (2002).

The above chemical assessment were used to judge the quality of silages according to Flieg (1952) who developed a scheme upon which points are awarded according to the relative amounts of lactic, acetic and butyric acids in silage. So that, the higher proportions of lactic and acetic acids to butyric acid had the higher score and the better quality. This system has gained wide acceptance in Europe and Germany. Another fresh sample from every silo was taken and prepared for microorganisms differential counts in silages by the plate culture count method according to Gibson et al. (1958) and Cai et al. (1998) for development extensively lactobacilli, clostridia, bacilli, entero-bacteria, yeasts and molds.

\section{Digestion trials:}

Eight digestion trials were carried out at the experimental farm of faculty of agriculture, Mans. Univ., using three mature healthy Ossimi rams in each group with an average live body weight of $48.6 \pm 0.87 \mathrm{~kg}$ and 2 years old to determine nutrients digestibility coefficients and nutritive values of the experimental silages. Each animal was confined in individual concrete pen for 15 days as an adaptation period followed by five days as a collection period. All rams were injected subcutaneously with anti-parasites at the beginning of the experiment. Animals were fed to cover $80 \%$ of their maintenance requirements (NRC, 1985).

The ingredients of concentrate feed mixture (CFM) which used were $60 \%$ of ground yellow corn, $20 \%$ soy bean meal ( $44 \%$ CP), $15 \%$ wheat bran, $1.5 \%$ premix, $2 \%$ calcium carbonate, $1 \%$ di-calcium phosphate and $0.5 \%$ sodium chloride, that were mixed manually. The chemical composition of CFM and berseem silages was illustrated at Table (1). The daily feed allowances were weighted and offered twice daily (at 8.0 AM and 4.0 PM) as $4.0 \mathrm{~kg}$ of every berseem silage plus $0.3 \mathrm{~kg}$ of CFM/head/day (as fresh matter). These amounts of berseem silage and CFM were constant in all groups. Drinking water was available to each animal allover the time. Samples of feeds were taken in the first and last of experiment and kept for later analysis. Feces samples were taken from the rectum during the collection period of each trial ( 5 days) and dried in forced air oven at $65^{\circ} \mathrm{C}$ for $48 \mathrm{hrs}$. Dried samples were composed for each animal and representative 
samples were taken, ground and kept for chemical analysis. Acid insoluble ash was used as a neutral marker according to Van Keulen and Young (1977). Digestibility coefficients were calculated from the equations given by Schneider and Flatt (1975).

DM digestibility \% = $100-[100 \times($ AIA \% in feed / AIA\% in feces $)]$

Nutrient digestibility $\%=100-[100 \times($ AlA $\%$ in feed $/$ AlA $\%$ in feces $)] \times$ [nutrient\% in feces / nutrient $\%$ in feed]

Proximate analysis of feedstuffs and feces was determined according to A.O.A.C. (1990). Samples of feeds and feces also were analyzed for fiber fractions according to the procedures of Van Soest, et al. (1991) to determine neutral detergent fiber (NDF), acid detergent fiber (ADF) and acid detergent lignin (ADL). Cellulose was calculated as $=$ ADF-ADL and Hemicellulose as $=$ NDF-ADF. Non-fibrous carbohydrates (NFC) were calculated as: NFC\% $=\mathrm{OM}$ - (\%NDF + \%CP + \%EE) (Calsamiglia et al., 1995). The quality index was calculated according to Moore (1994) as follow:

RFQ (relative feeding quality $)=($ DMl\% of BW $) \times($ TDN\% of DM) $/ 1.23$

$\mathrm{QI}$ (quality index) $=0.0125 \times \mathrm{RFQ}+0.097$

\section{Rumen fermentation:}

Rumen fluid samples were collected from all rams during the last day of collection period. The samples were taken by rubber stomach tube using gentle mouth suction. About $100 \mathrm{ml}$ of rumen fluid was collected just before offering the morning feed (zero time) and consequently at 2, 4 and $8 \mathrm{hr}$ post feeding (at timed interval). The collected samples were filtered through 4 layers of surgical gauze and were immediately used to determine rumen $\mathrm{pH}$ using digital $\mathrm{pH}$-meter. The effective natural detergent fiber (eNDF) was calculated as $=(\mathrm{pH}-5.425) / 0.04229$ according to Fox et al. (2000). Then samples were stored in dried bottles at $-20^{\circ} \mathrm{C}$ for measuring other parameters. Ammonia nitrogen $\left(\mathrm{NH}_{3}-\mathrm{N}\right)$ concentration was measured according to Conway (1957) method. Total volatile fatty acids (TVFA's) in rumen liquor were measured according to stem distillation procedure as described by Warner (1964). Rumen buffering capacity was also determined according to (Jasaitis et al., 1987) that total acidity was measured in the same sample by titration and expressed as $0.1 \mathrm{~N} \mathrm{HCl} \mathrm{ml} \mathrm{equivalent} \mathrm{required}$ to reduce the original $\mathrm{pH}$ to 4.5 .

\section{Blood metabolites:}

Blood samples were collected from each experimental animal after morning feeding in the $2^{\text {nd }}$ day of collection period via jugular vein using heparinized tubes. Blood plasma was separated by centrifugation at 3000 r.p.m for 10 minutes and stored at $-20^{\circ} \mathrm{C}$ until analyzed for the different blood parameters. Blood hemoglobin $(\mathrm{Hb})$, hematocrite $(\mathrm{HT})$, red blood cell counts (RBC's) and white blood cell counts (WBC's) were measured using auto blood counter (CD 1700 Speciment). Plasma glucose, total protein, createnine and aspartate aminotransferase (AST) were determined colorimetric using commercial kits according to the procedures outlined by the manufacture. 
Abd El-Hady, M. A. A. et al.

Table (1): Chemical composition of CFM, silages and calculated experimental rations as affectedby wilting and chopping with or without formic acid treatments of berseem silage.

\begin{tabular}{|c|c|c|c|c|c|c|c|c|c|c|c|c|c|}
\hline \multirow{2}{*}{ Items } & \multirow{2}{*}{ DM } & \multicolumn{12}{|c|}{ Chemical Composition (\% as DM) } \\
\hline & & OM & $\mathbf{C P}$ & EE & CF & NFE & Ash & NDF & ADF & ADL & Hemi. & Cellu. & NFC \\
\hline \multicolumn{14}{|c|}{ Ingredients } \\
\hline CFM & 88.45 & 91.84 & 18.4 & 1.94 & 12.4 & 59.1 & 8.16 & 29.1 & 12.6 & 6.1 & 16.5 & 6.48 & 41.3 \\
\hline $\mathbf{S 1}$ & 15.66 & 83.15 & 17.1 & 2.32 & 34.7 & 29.0 & 16.85 & 43.1 & 27.1 & 7.4 & 16.0 & 19.7 & 18.2 \\
\hline S2 & 13.32 & 84.95 & 16.9 & 2.55 & 33.3 & 32.2 & 15.05 & 44.9 & 25.8 & 8.0 & 19.2 & 17.8 & 18.4 \\
\hline S3 & 19.88 & 84.46 & 16.4 & 2.69 & 35.7 & 29.7 & 15.54 & 45.5 & 28.4 & 7.3 & 17.1 & 21.1 & 17.3 \\
\hline S4 & 19.85 & 83.83 & 16.8 & 2.37 & 33.2 & 31.5 & 16.17 & 45.2 & 28.6 & 8.2 & 16.6 & 20.4 & 16.9 \\
\hline S5 & 31.95 & 84.23 & 16.1 & 2.65 & 33.6 & 31.9 & 15.77 & 46.0 & 28.9 & 8.4 & 17.0 & 20.6 & 17.5 \\
\hline S6 & 29.85 & 84.05 & 16.2 & 2.52 & 35.1 & 30.2 & 15.95 & 46.1 & 30.7 & 7.9 & 15.3 & 22.8 & 16.6 \\
\hline \begin{tabular}{|l|} 
S7(un- \\
Chopped s.)
\end{tabular} & 20.32 & 83.76 & 16.0 & 2.65 & 34.6 & 30.5 & 16.24 & 49.7 & 35.0 & 7.9 & 14.6 & 27.1 & 12.7 \\
\hline $\begin{array}{l}\text { S8(un- } \\
\text { Chopped s.) }\end{array}$ & 24.59 & 83.32 & 15.3 & 2.27 & 36.0 & 29.8 & 16.68 & 50.1 & 36.8 & 7.7 & 13.3 & 29.1 & 12.8 \\
\hline \multicolumn{14}{|c|}{ Experimental rations } \\
\hline $\mathbf{R 1}$ & 20.74 & 87.00 & 17.5 & 2.21 & 28.0 & 36.0 & 13.00 & 38.9 & 22.8 & 7.01 & 16.2 & 15.8 & 25.1 \\
\hline R2 & 18.56 & 87.91 & 17.4 & 2.30 & 26.3 & 41.9 & 12.09 & 39.7 & 21.4 & 7.38 & 18.3 & 14.0 & 26.0 \\
\hline R3 & 24.66 & 87.81 & 16.9 & 2.50 & 29.9 & 38.5 & 12.19 & 41.4 & 24.4 & 6.98 & 17.0 & 17.4 & 23.3 \\
\hline R4 & 24.63 & 82.61 & 17.2 & 2.26 & 28.0 & 35.2 & 17.39 & 41.1 & 24.6 & 7.71 & 16.6 & 16.9 & 23.0 \\
\hline $\mathbf{R 5}$ & 35.89 & 81.38 & 17.0 & 2.53 & 29.9 & 31.9 & 18.62 & 43.1 & 26.1 & 7.99 & 16.9 & 18.1 & 21.6 \\
\hline R6 & 33.94 & 84.49 & 17.1 & 2.41 & 30.9 & 34.1 & 15.51 & 43.0 & 27.4 & 7.62 & 15.5 & 19.8 & 21.1 \\
\hline R 7 & 25.07 & 85.75 & 16.6 & 2.47 & 29.1 & 37.6 & 14.25 & 44.6 & 29.5 & 7.90 & 15.1 & 22.0 & 19.8 \\
\hline R 8 & 29.04 & 85.13 & 15.9 & 2.20 & 31.0 & 36.0 & 14.87 & 45.7 & 31.7 & 8.11 & 14.0 & 24.3 & 18.9 \\
\hline
\end{tabular}

\section{Statistical analysis:}

Data of the study were analyzed using the General Linear Model (GLM) of SAS (2004). In chopped silage groups, data of nutrients digestibility, feeding values and blood parameters were analyzed using two ways classification model included wilting, formic and interaction between them. Whereas, rumen parameters was subjected using factorial design analysis of variance model included wilting, formic, time and their interactions. Data of un-chopped silages digestibility were analyzed using one way classification model included formic acid effect. Whereas, rumen parameters of unchopped silages were analyzed two ways classification model included formic acid, time and their interactions. The differences among overall means were compared using Duncan's multiple range test (Duncan, 1955).

\section{RESULTS AND DISCUSSION}

Data of the chemical composition of CFM, berseem silages and experimental rations are presented in Table (1). The DM\% of un-wilted silages (S1 and S2) with or without formic acid was the lowest values $(15.66$ and $13.32 \%$, respectively), whereas DM\% was around $20 \%$ and $30 \%$ of berseem silages wilted for 24 and $48 \mathrm{hr}$, respectively. The CP of silage ranged from 14.8 to $17.1 \%$. Wilted berseem silage (S3 and S4) for $48 \mathrm{hr}$ had the highest value of NDF\% and ADF\% and the lowest value of NFC\% as DM basis compared with the other treatments. The other chemical nutrients were 
slightly varied among groups. Similar trend was found with their experimental rations. The composition of un-chopped silages (S7 and S8) was similar to those chopped silages except for fiber fractions. The un-chopped silage was higher in NDF\% and ADL\%, whilst the lowest percent of CP\% was in unchopped treated silage.

These data are agreed with those of Haigh and Mansbridge (1998) and Abou El-Enin, (2005) who ensiled perennial ryegrass and berseem clover (BC), respectively. Shrestha et al. (1998) and Mustafa and Seguin (2003) reported that NDF of BC silage ranged between 36.9 to $45.5 \%$ and ADF ranged 25.7 to $33 \%$. In this respect, the results are in accordance to those findings by Touqir et al. (2007) who found similar most composition of berseem silage at different levels of DM (17.2, 20 and 30\%).

Silage fermentation and quality:

Physical characteristics of wilted silage without formic acid treatment had a dark green color and a vinegar un-palatable smell. Whereas, wilted silage and treated with formic acid had a yellowish olive green color and palatable very good smell due to high lactic acid concentration. Berseem silage which neither un-wilted nor un-treated with formic acid had a dark green color, high moisture and low smell, while the treated silage had a better smell and a light green color. Opening the untreated silage with formic acid (S1, S3, S5 and S7, respectively) were covered by excessive layer of molds which excluded before feeding, whereas the treated silages were clarified from the molds.

Fermentation parameters of berseem silages and their evaluation are presented in Table (2). Silage wilted for $24 \mathrm{hr}$ (S3) had the lowest value of $\mathrm{pH}$ (5.07) compared with untreated silages. The highest value of $\mathrm{pH}$ was recorded with wilted silage for $48 \mathrm{hr}$ (without any additives) followed by unchopped silages (S7 and S8). The decline of pH in chopped silages than unchopped can be in direct response to release of organic acids contained in the cell sap (Woolford, 1984). Whereas, sprinkled formic acid was more effective than wilting in reducing $\mathrm{pH}$ value, therefore the lowest value of $\mathrm{pH}$ was 3.87 in wilted silage for $24 \mathrm{hr}$ and treated with formic (S4) owing to the associated effect for wilting and formic acid treatments. However, increasing the wilting time for $48 \mathrm{hr}$ with formic acid treatment (S6) had a worst effect on $\mathrm{pH}$ value of silage (being $\mathrm{pH}$ 4.49). Lactic acid concentration slightly increased by wilting only for $24 \mathrm{hr}$ (S3) and quadratic by wilting and formic acid treatments (S4 and S6). The highest value of lactate was 3.15\% followed by $3.06 \%$ for S4 and S6, respectively. The lowest value of lactate was recorded in un-chopped silage $(0.92-0.99 \%)$. It is very difficult to compress the un-chopped forage materials especially berseem forage due to its tube stems. So that, it could not be remove the penetrated air completely resulted in bad fermentation, higher DM losses and higher pH value (Ruxton, 1972; Rees et al., 1983). 
Abd El-Hady, M. A. A. et al.

Table (2): Effect of wilting and chopping with or without formic acid supplement on some fermentation characteristics and silage quality.

\begin{tabular}{|c|c|c|c|c|c|c|c|c|c|c|}
\hline \multirow[b]{2}{*}{ Treatment } & \multirow[b]{2}{*}{$\mathrm{pH}$} & \multicolumn{4}{|c|}{ VFA's (\% as DM) } & \multirow[b]{2}{*}{ TVFA's } & \multirow{2}{*}{$\begin{array}{l}\text { Lactic/ } \\
\text { TVFA's }\end{array}$} & \multirow{2}{*}{$\begin{array}{l}\text { Lactic/ } \\
\text { Acetic }\end{array}$} & \multirow{2}{*}{$\begin{array}{l}\text { Fleig } \\
\text { point }\end{array}$} & \multirow{2}{*}{$\begin{array}{c}\text { Classifica } \\
\text {-tion }\end{array}$} \\
\hline & & $\begin{array}{l}\text { Lactic } \\
\text { acid }\end{array}$ & Acetic & $\begin{array}{l}\text { Propi- } \\
\text { onic }\end{array}$ & Butyric & & & & & \\
\hline \multicolumn{11}{|c|}{ Chopped silage: } \\
\hline S1 & 5.15 & 1.49 & 21.11 & 0.13 & 1.31 & 24.05 & 0.062 & 0.07 & 34 & Poor \\
\hline S2 & 4.05 & 2.57 & 3.01 & 0.15 & 0.06 & 5.79 & 0.444 & 0.85 & 65 & good \\
\hline S3 & 5.07 & 1.65 & 10.70 & 0.16 & 1.67 & 14.2 & 0.116 & 0.15 & 28 & Poor \\
\hline S4 & 3.87 & 3.15 & 1.57 & 0.14 & ND & 4.87 & 0.647 & 2.00 & 90 & Very good \\
\hline $\mathbf{S 5}$ & 5.80 & 1.04 & 2.94 & 0.13 & 0.04 & 4.15 & 0.250 & 0.35 & 48 & Medium \\
\hline S6 & 4.49 & 3.06 & 1.78 & 0.16 & ND & 4.99 & 0.613 & 1.72 & 86 & Very good \\
\hline \multicolumn{11}{|c|}{ Un-chopped silage: } \\
\hline S7 & 5.67 & 0.92 & 22.11 & 0.37 & 1.94 & 8.55 & 0.11 & 0.17 & 15 & Bad \\
\hline S8 & 5.55 & 0.99 & 5.32 & 0.11 & 1.01 & 24.23 & 0.04 & 0.05 & 34 & Poor \\
\hline
\end{tabular}

S1= un-wilted silage, no formic; S2= un-wilted, treated with formic; S3= wilted for $24 \mathrm{hr}$, no formic; S4= wilted for $24 \mathrm{hr}$, treated with formic; S5= wilted for $48 \mathrm{hr}$, no formic; S6= wilted for $48 \mathrm{hr}$, treated with formic; S7= un-chopped, no formic; S8= un-chopped, treated with formic acid; ND: not detected

The ratios of lactic: TVFA's and lactic: acetic had shown corresponding trend. So, the highest ratio was obtained with S4 silage (being 0.647 and 2.00 , respectively) followed by S6 silage $(0.613$ and 1.72$)$ and S2 silage (0.444 and 0.85). The result can be explained the greater values of lactobacilli count (Table 3) in wilted and formic acid treated silages (being 5.2 and 5.0 Log ${ }_{10} \mathrm{cfu} / \mathrm{g}$ for S4 and S6, respectively). The concentrations of acetic and butyric acids of silage were declined linearly with both wilting and formic acid treatment. The lowest value of acetic was in S4 followed by S6 silages and the highest value was showed with un-wilted and untreated silage with formic acid (S1). Likewise, butyric acid was not detected in both S4 and S6 but the highest value was in un-chopped and untreated with formic acid (S7) which indicate to the deterioration of protein and the lactate to butyrate by clostridia (McDonald, 1981). Whereas, propionic acid concentration was slightly differed among groups. The TVFA's was in the minimum levels in wilted and treated with formic silages, which indicate a good quality and more palatable silage, consequently improved feed intake (Jatkauskas and Vrotniakiene, 2006).

Table (3): Effect of wilting and chopping with or without formic acid treatment on microorganisms counts $\left(\log _{10} \mathrm{CFU} / \mathrm{g}\right.$ silage).

\begin{tabular}{|l|c|c|c|c|c|c|}
\hline Items & Lactobacilli & Yeasts & Molds & Entero-bacterid & Clostridia & Bacilli \\
\hline Chopped silage: \\
\hline S1 & 3.9 & 3.9 & 2.9 & 6.9 & 2.6 & 2.6 \\
\hline S2 & 4.1 & 4.1 & 1.8 & 4.6 & 2.1 & 2.7 \\
\hline S3 & 3.6 & 2.3 & 2.7 & 6.8 & 2.2 & 2.4 \\
\hline S4 & 5.2 & 2.5 & 1.4 & 4.5 & 2.0 & 2.2 \\
\hline S5 & 3.5 & 3.3 & 2.2 & 5 & 2.1 & 2.5 \\
\hline S6 & 5.0 & 3.9 & 1.7 & 4.7 & 1.9 & 2.2 \\
\hline Un-chopped silage: & 3.0 & 2.2 & 2.4 & 6.0 & 2.5 & 2.4 \\
\hline S7 & 3.2 & 2.1 & 1.6 & 5.9 & 2.2 & 2.5 \\
\hline S8 & \multicolumn{5}{|l}{} \\
\hline
\end{tabular}


The Fleig point is a summative record, which used to evaluate the quality of silage. According to Fleig point (Table 2), the best quality of silage was S4 followed by S6 (being 90 and 86, respectively). While, the lowest value was recorded in un-chopped silage (S7; being 15), followed by S3. The formic acid treatment improved the quality score of un-chopped berseem but still poor quality. Corresponding results are in Table (3) which concluded that S4 and S6 had the lowest values of undesirable microorganisms as molds, entero-bactria, clostridia and bacilli spp. so that, the entero-bacteria can be metabolite glucose to acetate and the clostridia can be metabolite lactate to butyrate leading to DM and energy losses by about $51 \%$ and $18.4 \%$, respectively (McDonald et al., 1973). According to the results in Tables 2 and 3 it was found a positive correlation between acetic acid and entero-bacteria count as well as between butyric acid and clostridia count. These findings are in agreement with Suepea et al. (2000) who found that $\mathrm{pH}$ value of berseem silage with added corn meal was 4.21 and 7.54 when chopped and unchopped, respectively. Moreover, Fleig point was 61 and 21, respectively. As well as, Abou El-Enin (2005) found that wilted berseem silage and treated with formic acid had a lowest value of $\mathrm{pH}$ and butyric acid concentration and the highest value of lactic acid concentration and consequently the highest value of Fleig-zimmer point as very good silage. Zhang (2011) found that chopping of guinea grass at $3 \mathrm{~cm}$ was beneficial to lactic acid fermentation and all fermentation parameters except $\mathrm{NH}_{3}-\mathrm{N}$ content compared with 1 and $6 \mathrm{~cm}$ of length. In accordance findings, Rowghani and Zamiri (2009) found that corn silage treated with formic acid was significantly $(P<0.05)$ higher in lactic acid, total acids concentration and higher $(P>0.05)$ in lactic: acetic ratio compared with inoculants treated or untreated silage. Likewise, the earlier investigation showed lucerne silage treated with $1.5-6.0 \mathrm{l} / \mathrm{t}$ had greater levels of lactic acid and lower values of $\mathrm{pH}$, acetic, propionic and butyric acid concentration (Barry et al., 1978) which are in accordance with the present results. In this field, Polan et al. (1998) reported that direct-cut alfalfa plus formic acid had more favorable fermentation as well as a lower $\mathrm{pH}$, greater lactic acid and greater water soluble carbohydrate compared with wilted alfalfa plus anhydrous $\mathrm{NH}_{3}$. Similar results were found by Etman et al. (1995) who found the $\mathrm{pH}$ value of berseem silage treated with formic acid was 3.9 compared with molasses ( $\mathrm{pH}$ 4.62). Jatkauskas and Vrotniakiene (2006) illustrated that formic acid treatment to ensiled red clover-grass mixture (3:1) reduced $(P<0.01) \mathrm{pH}$ values $(4.30$ vs. 4.51$)$ and elevated $(P<0.01)$ lactic acid concentration (4.32 vs. $3.15 \%)$, as well as reduced acetic (1.3 vs. $2.5 \%)$ and butyric acids (0.014 vs. $0.3 \%$ ). Touqir et al. (2007) showed a similar values of $\mathrm{pH}$ and lactic acid values for berseem silages treated with different levels of $\mathrm{DM}$ and molasses. They proposed that the best values of $\mathrm{pH}$ and lactic acid were in $30 \%$ DM, whilst in the present study the best values were at $20 \% \mathrm{DM}$ of silage treated with Formic acid. Fransen and Strubi (1998) reported that wilting was an effective treatment in young napier grass to lower $\mathrm{pH}$ value compared with fresh young napier grass silage. They also found that the $\mathrm{pH}$ value of direct cut silage of this grass was 5.09 while wilted silage had a pH 4.72. Gordon et al. (1999) found that un-wilted ryegrass and treated with 
Abd El-Hady, M. A. A. et al.

formic (19.4\% DM) had better values of $\mathrm{pH}$ and lactic acid than wilted and treated with formic ryegrass ( $46 \% \mathrm{DM})$.

The results are in accordance with Suepea et al. (2000) who reported that wilted berseem clover silage (25\% DM) had the lowest value of butyric (being $0.005 \%$ ) and $\mathrm{pH} 4.21$ with Flieg score 75 compared with score 70 in wilted berseem silage (36\% DM). Carpintero et al. (1969) concluded that formic acid silage results in highly negative correlation between level of addition and proteolysis together with deamination. However, wilting is important factor for ensiling the high moisture forages legumes as berseem to increase DM, Henderson et al. (1972) found that during a $31 \mathrm{hr}$ with DM content of $32 \%, 20 \%$ of initial protein was hydrolyses. There is general agreement that the extent of proteolysis is increased by extending the wilting period and, more important, by wilting under humid conditions (McDonald et al., 1991). So that, the best period for wilting chopped berseem was $24 \mathrm{hr}$. during spring season under humid local conditions, together with $0.5 \%$ formic acid treatment at ensiling process.

Nutrients digestibility:

Data of nutrients digestibility are shown in Tables (4 and 5). The unwilted berseem silage ration with or without formic acid treatment was the highest $(\mathrm{P}<0.05)$ significantly of $\mathrm{DM}, \mathrm{OM}, \mathrm{CP}, \mathrm{EE}$ and CF\% digestibility. The differences between $0 \mathrm{hr}$ and $24 \mathrm{hr}$ were not significant. This may be related to total dry matter intake (TDMI) which was the lowest value in un-wilted silage and resulted in increase the rate of passage of the feed (Shaver et al., 1986). As well as, the biochemical losses from respiration and deamination of wilted silage could be higher than losses from un-wilted silage and digestibility of the silage is reduced (Thomas and Thomas, 1985). Whereas, NFE, NFC and fiber fraction did not differ significantly among wilting groups.

Otherwise, formic acid treatment of silage ration increased $(P<0.05)$ the digestibility of most nutrients compared with untreated silage except for CP\% that reduced $(P<0.05)$ by treatment, which are in agreement with Handerson et al. (1982). Digestibility of ADF, ADL and hemicellulose tend to be higher in treated silage with formic acid than untreated but without significant differences. The nutrients digestibility was not affected significantly by interaction between wilting and formic acid treatment. Generally, the digestibility of nutrients in un-chopped silage ration was lower (not statistically) than chopped silage except for CF and its fractions. Treated un-chopped silage with formic acid was slightly higher in most nutrients digestibility than untreated un-chopped silage ration. 
Table (4): Nutrients digestibility and feeding values of experimental rations as affected by wilting and chopping with or without formic acid treatment of berseem silage with sheep.

\begin{tabular}{|c|c|c|c|c|c|c|c|c|c|c|c|c|c|}
\hline \multirow{3}{*}{ Items } & \multicolumn{10}{|c|}{ Chopped silage } & \multirow{2}{*}{\multicolumn{3}{|c|}{$\begin{array}{l}\text { Un-chopped } \\
\text { silage }\end{array}$}} \\
\hline & \multicolumn{4}{|c|}{ Wilting (hr) } & \multicolumn{3}{|c|}{ Formic } & \multicolumn{3}{|c|}{ Significance } & & & \\
\hline & 0 & 24 & 48 & SE & $-F$ & $+\mathbf{F}$ & SE & W & $\mathbf{F}$ & WxF & $-F$ & $+\mathbf{F}$ & SE \\
\hline TDMI, kg & 0.845 & 1.06 & 1.50 & - & 1.16 & 1.11 & - & - & - & - & 1.08 & 1.25 & - \\
\hline TDMI/BW\% & $1.73^{c}$ & $2.19^{b}$ & $3.11^{\mathrm{a}}$ & 0.03 & 2.40 & 2.28 & 0.03 & ** & ** & * & 1.96 & 2.47 & $0.06^{* \star}$ \\
\hline \multicolumn{14}{|l|}{ Digestibility\% } \\
\hline DM & $66.8^{a}$ & $65.3^{\mathrm{ab}}$ & $63.5^{b}$ & 0.64 & 64.4 & 66.0 & 0.52 & * & * & NS & 63.3 & 62.3 & 0.77 \\
\hline OM & $72.0^{a}$ & $71.7^{\mathrm{a}}$ & $69.4^{b}$ & 0.48 & 70.3 & 71.7 & 0.39 & ** & * & NS & 67.3 & 66.9 & 0.87 \\
\hline $\mathbf{C P}$ & $69.8^{a}$ & $70.1^{\mathrm{a}}$ & $67.2^{0}$ & 0.51 & 70.4 & 67.7 & 0.42 & ** & ** & NS & 65.5 & 62.5 & 1.26 \\
\hline EE & $70.1^{a}$ & $71.1^{a}$ & $67.3^{b}$ & 0.74 & 68.4 & 70.7 & 0.60 & ** & * & NS & 68.2 & 69.2 & 0.95 \\
\hline CF & $59.3^{a}$ & $59.9^{a}$ & $56.9^{b}$ & 0.53 & 57.9 & 59.5 & 0.43 & ** & * & NS & 58.8 & 61.6 & 1.42 \\
\hline NFE & 82.4 & 81.7 & 82.2 & 1.19 & 80.9 & 83.3 & 0.97 & NS & NS & NS & 74.2 & 74.9 & 1.37 \\
\hline NDF & 59.8 & 59.1 & 57.2 & 0.96 & 57.5 & 59.8 & 0.78 & NS & ${ }^{*}$ & NS & 59.5 & 60.3 & 1.39 \\
\hline ADF & 39.8 & 40.5 & 40.9 & 0.97 & 39.3 & 41.5 & 0.80 & NS & NS & NS & 42.8 & 46.4 & 1.46 \\
\hline ADL & 17.1 & 16.5 & 17.0 & 1.68 & 16.9 & 16.8 & 1.37 & NS & NS & NS & 18.3 & 21.3 & 0.88 \\
\hline Hemice. & 85.4 & 86.3 & 84.0 & 1.22 & 84.1 & 86.4 & 0.99 & NS & NS & NS & 92.1 & 91.6 & 1.46 \\
\hline Cellulose & 51.0 & 50.8 & 50.7 & 1.34 & 48.9 & 52.6 & 1.10 & NS & ${ }^{*}$ & NS & 51.2 & 54.0 & 1.87 \\
\hline NFC & 92.5 & 95.3 & 96.6 & 1.36 & 93.5 & 96.2 & 1.11 & NS & NS & NS & 84.7 & 88.4 & 1.29 \\
\hline \multicolumn{14}{|c|}{ Nutritive value \% } \\
\hline TDN\% & $62.9^{\mathrm{a}}$ & $61.4^{\mathrm{b}}$ & $60.4^{\mathrm{b}}$ & 0.39 & 61.2 & 61.9 & 0.32 & ** & NS & * & 58.0 & 57.5 & 0.74 \\
\hline TDNI, kg/d & $0.531^{\mathrm{c}}$ & $0.651^{b}$ & $0.907^{a}$ & 0.004 & 0.71 & 0.68 & 0.003 & ** & $\star \star$ & * & 0.625 & 0.719 & $0.01^{\star \star}$ \\
\hline DCP\% & $12.2^{\mathrm{a}}$ & $11.9^{\mathrm{a}}$ & $11.4^{\mathrm{b}}$ & 0.09 & 12.1 & 11.6 & 0.07 & ** & 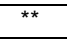 & NS & 10.9 & 9.9 & $0.20^{*}$ \\
\hline TDN/CP & 3.61 & 3.60 & 3.54 & 0.02 & 3.57 & 3.60 & 0.02 & NS & NS & ** & 3.49 & 3.62 & 0.046 \\
\hline ME, Mcal/kg & $2.24^{a}$ & $2.18^{b}$ & $2.15^{b}$ & 0.014 & 2.18 & 2.20 & 0.01 & $\star *$ & NS & ** & 2.06 & 2.05 & 0.026 \\
\hline MEI, Mcal/d & $1.89^{\mathrm{C}}$ & $2.32^{b}$ & $3.23^{a}$ & 0.01 & 2.53 & 2.42 & 0.01 & ** & $* *$ & * & 2.22 & 2.56 & $0.03^{* *}$ \\
\hline $\mathrm{NE}^{1}, \mathrm{Mcal} / \mathbf{k g}$ & $1.42^{\mathrm{a}}$ & $1.38^{b}$ & $1.36^{b}$ & 0.01 & 1.38 & 1.40 & 0.01 & ** & NS & * & 1.30 & 1.29 & 0.018 \\
\hline RFQ & $88.4^{\mathrm{C}}$ & $109.1^{b}$ & $152.7^{a}$ & 1.31 & 119.3 & 114.2 & 1.07 & ** & * & * & 92.5 & 115.6 & $3.75^{*}$ \\
\hline QI & $1.20^{\mathrm{C}}$ & $1.46^{\mathrm{b}}$ & $2.00^{\mathrm{a}}$ & 0.016 & 1.58 & 1.52 & 0.01 & ** & * & * & 1.25 & 1.54 & $0.047^{*}$ \\
\hline
\end{tabular}

${ }^{1} \mathrm{NE}(\mathrm{Mcal} / \mathrm{kg})=($ TDN\% $\times 0.0245)-0.12(\mathrm{NRC}, 2001) ;$ TDMl= total dry matter intake ; $-\mathrm{F}=$ without formic ; $+\mathrm{F}=$ with formic

a, b and c lest square means in the same row for chopped silage with different superscript differ significantly $(\mathrm{P}<0.05)$

${ }^{\star} \mathrm{P}<0.05 ;{ }^{\star \star} \mathrm{P}<0.01 ; \mathrm{NS}=$ non-significant

The nutritive value (TND, DCP, ME and NE) of un-wilted berseem silage ration was significantly greater $(P<0.01)$, whilst it was the lowest $(P<0.01)$ TDNI, MEl, relative feeding quality (RFQ) and quality index (QI) values compared with wilted silage rations. The lowest value of TDNI and MEI in un-wilted silage could be due to lower DMI. Nutritive value was affected $(P<0.01)$ by interaction between wilting and formic acid treatment, which was greater in un-wilted silage treated with formic acid (Table 5). The un-chopped silage ration had lower (not statistically) nutritive value and QI compared with chopped silages. The index of quality measures the voluntary intake of TDN above maintenance. When forage is fed without supplemental energy or protein, QI is related to the available TDN for the gain (Moore and Kunkle, 1995). Therefore, the treatment with formic plus pre-ensiled wilting improved the efficiency of ensiled berseem. 
Abd El-Hady, M. A. A. et al.

Table (5): Nutrients digestibility and feeding values of experimental rations as affected by the interaction between wilting and formic acid treatment of berseem silage.

\begin{tabular}{|c|c|c|c|c|c|c|c|c|}
\hline \multirow{3}{*}{ Items } & \multicolumn{8}{|c|}{ Chopped silage } \\
\hline & \multirow{2}{*}{\begin{tabular}{|l|} 
Wilting (hr) \\
Formic acid
\end{tabular}} & \multicolumn{2}{|c|}{0} & \multicolumn{2}{|c|}{24} & \multicolumn{2}{|c|}{48} & \multirow[t]{2}{*}{ SE } \\
\hline & & $-F(R 1)$ & $+F(R 2)$ & -F (R3) & $+F(R 4)$ & -F (R5) & $+F(R 6)$ & \\
\hline BW & & 49.0 & 48.7 & 49.0 & 48.0 & 48.0 & 48.7 & - \\
\hline TDDMI, & & 0.89 & 0.80 & 1.06 & 1.06 & 1.54 & 1.46 & - \\
\hline TDMI/ & & 1.82 & 1.64 & 2.16 & 2.21 & 3.22 & 3.00 & 0.046 \\
\hline \multicolumn{9}{|c|}{ Nutrient: digestibility, \%: } \\
\hline DM & & 65.9 & 67.6 & 64.6 & 65.9 & 62.6 & 64.4 & 0.91 \\
\hline OM & & 71.1 & 72.9 & 70.9 & 72.4 & 68.9 & 69.8 & 0.68 \\
\hline $\mathbf{C P}$ & & 71.1 & 68.5 & 71.4 & 68.7 & 68.6 & 65.9 & 0.72 \\
\hline EE & & 68.5 & 71.7 & 69.6 & 72.7 & 67.0 & 67.7 & 1.04 \\
\hline CF & & 58.3 & 60.3 & 58.6 & 61.1 & 56.9 & 57.0 & 0.74 \\
\hline NFE & & 81.3 & 83.4 & 81.4 & 82.1 & 80.1 & 84.4 & 1.68 \\
\hline NDF & & 58.4 & 61.2 & 58.1 & 60.1 & 56.1 & 58.3 & 1.36 \\
\hline ADF & & 39.4 & 40.2 & 39.6 & 41.4 & 39.1 & 42.9 & 1.38 \\
\hline ADL & & 16.8 & 17.4 & 15.8 & 17.1 & 18.1 & 16.1 & 2.37 \\
\hline Hemic & ulose & 85.2 & 85.7 & 84.9 & 87.8 & 82.3 & 85.7 & 1.73 \\
\hline Cellul & & 49.4 & 52.2 & 49.1 & 52.5 & 48.3 & 53.2 & 1.90 \\
\hline NFC & & 91.2 & 93.9 & 93.4 & 97.2 & 95.8 & 97.4 & 1.92 \\
\hline \multicolumn{9}{|c|}{ Feeding value: } \\
\hline TDN\% & & 61.4 & 64.4 & 61.9 & 60.8 & 60.3 & 60.5 & 0.56 \\
\hline TDNI, & & 0.55 & 0.51 & 0.66 & 0.64 & 0.93 & 0.88 & 0.01 \\
\hline DCP\% & & 12.4 & 11.9 & 12.1 & 11.8 & 11.7 & 11.2 & 0.122 \\
\hline TDN/C & & 3.52 & 3.71 & 3.66 & 3.54 & 3.54 & 3.55 & 0.032 \\
\hline MEI, N & I/d & 1.95 & 1.83 & 2.34 & 2.29 & 3.31 & 3.14 & 0.02 \\
\hline ME, M & $/ \mathbf{k g}$ & 2.19 & 2.29 & 2.21 & 2.17 & 2.14 & 2.15 & 0.02 \\
\hline NE, M & kg & 1.38 & 1.46 & 1.40 & 1.37 & 1.36 & 1.36 & 0.014 \\
\hline RFQ & & 90.9 & 85.8 & 109.0 & 109.2 & 157.8 & 147.5 & 1.852 \\
\hline Q & & 1.23 & 1.17 & 146 & 1.47 & 2.07 & 1.94 & 0.023 \\
\hline
\end{tabular}

The obtained results are in agreement with those reported by Etman et al. (1995) who found that digestion coefficients of all nutrients of berseem silage treated with $0.4 \%$ formic acid were elevated compared with that containing 3\% molasses. Similar results have been reported by Mayne and Steen (1990); Kokkonen et al. (2000); Jatkauskas and Vrotniakiene (2006) and Sarwar et al. (2005). Whereas, Aksu et al. (2005) illustrated that there were no significant effect of formic acid treatment for DM, OM, NDF or ADF digestibility in corn silage. The obtained results are consistent with Gordon et al. (1999) who found that the un-wilted ray grass silage had higher $(P<0.05)$ digestibility of DM, OM and GE. Similar results were found by Wilkins (1984) and Rohr and Thomas, (1984). However, other workers have not generally recorded such major negative effects of wilting on digestibility where rapid wilting techniques have been adopted (Yan et al., 1996 and 1998; Dawson et al., 1998). Donaldson and Edwards (1976) showed that DM, OM, CP digestibility and ME were higher in un-wilted grass silage than wilted, as well as formic acid treatment improved digestion coefficient of wilted silage.

\section{Rumen Fermentation:}

The data of rumen liquor parameters are presented in Tables $(6$ and 7). There was no significant interaction between sampling time and either wilting or formic for any characteristics measured except for $\mathrm{pH}$ and eNDF, therefore it was not showed in tables. The $\mathrm{pH}$ values of rumen liquor and calculated eNDF were not affected significantly by wilting or formic acid 
treatment. Whereas, the interaction between wilting and formic was significant $(\mathrm{P}<0.05)$, since the highest value of $\mathrm{pH}$ and eNDF was in $\mathrm{R} 6$ and the lowest value was in R4 than other groups (Table 7). The lowest $(P<0.01)$ values of $\mathrm{pH}$ and eNDF was in wilted group for $24 \mathrm{hr}$ at 0,2 and $4 \mathrm{hr}$ (Fig 1) and it was elevated in the last time of sampling. The $\mathrm{pH}$ values ranged from 7.4 to 6.6 with significant differences $(P<0.01)$ among sampling times. Ammonia- $N$ concentration was significantly $(P<0.01)$ higher in group fed silage ration wilted for $24 \mathrm{hr}$ than others, also it was elevated $(P<0.01)$ by formic acid treatment (16.4 vs. $14.7 \mathrm{mg} / \mathrm{dl})$. The interaction between the main factors was not significant. Similar trend was observed with TVFA's, which was increased by wilting time $(P<0.01)$ and formic acid treatment $(P>0.05)$. The highest $(P<0.01)$ value of TVFA's was in $R 4$ group and the lowest value was in R1 (being 7.28 vs. $4.20 \mathrm{mleq} / \mathrm{dl}$; Table 7). Buffering capacity of rumen was not affected by wilting, formic or their interactions, which related with rumen $\mathrm{pH}$ values. The results showed that the decreasing $\mathrm{pH}$ values after feeding at $2 \mathrm{hr}$ owing to increase $\mathrm{NH}_{3}-\mathrm{N}$ and TVFA's and thereafter $\mathrm{pH}$ was returned to elevate with declining $\mathrm{NH}_{3}-\mathrm{N}$ and TVFA's (Fig. 1 and 2). The $\mathrm{pH}$ value and calculated eNDF\% were higher in un-chopped silage than chopped. Whereas, rumen parameters except for buffering capacity were tend to be higher in un-chopped silage and treated with formic acid compared with that untreated.

Table (6): Rumen liquor parameters affected by wilting, chopping with or without formic acid treatment of berseem silage with sheep.

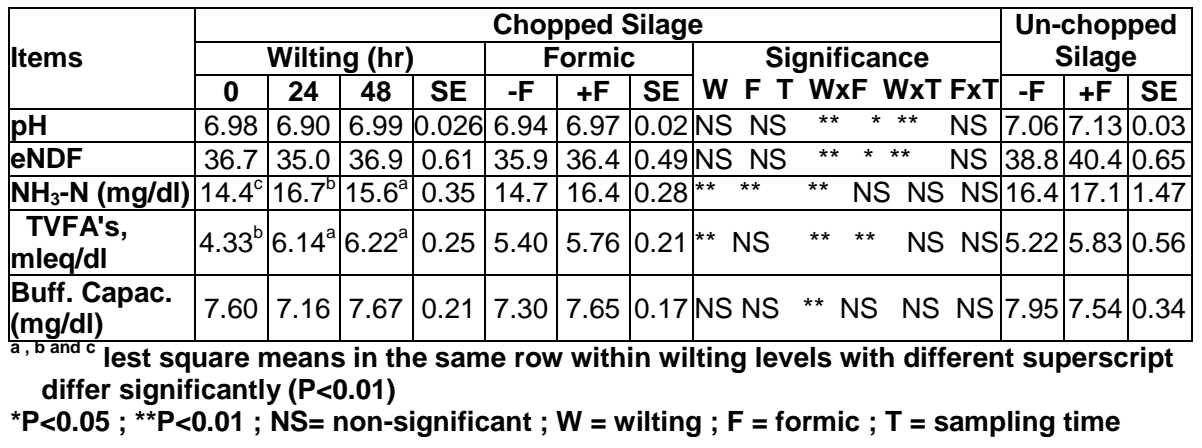

Table (7): Rumen liquor parameters affected by interaction between wilting and formic acid treatment of berseem silage with sheep.

\begin{tabular}{|c|c|c|c|c|c|c|c|c|}
\hline \multirow{3}{*}{ Items } & \multicolumn{8}{|c|}{ Chopped Silage } \\
\hline & \multirow{2}{*}{$\begin{array}{l}\text { Vilting (hr) } \\
\text { Formic } \\
\end{array}$} & \multicolumn{2}{|c|}{0} & \multicolumn{2}{|c|}{24} & \multicolumn{2}{|c|}{48} & \multirow[t]{2}{*}{ ISE } \\
\hline & & -F (R1) & $+F(R 2)$ & -F (R3) & $+F(R 4)$ & -F (R5) & $+F(R 6)$ & \\
\hline & 7.01 & 6.94 & 6.93 & 6.88 & 6.89 & 7.07 & 0.036 \\
\hline \multicolumn{2}{|c|}{ eNDF } & 37.4 & 35.9 & 35.6 & 34.3 & 34.8 & 39.0 & 0.86 \\
\hline \multicolumn{2}{|c|}{ NH3-N (mg/dl) } & 13.0 & 15.7 & 16.4 & 17.1 & 14.9 & 16.4 & 0.49 \\
\hline \multicolumn{2}{|c|}{ TVFA's (mleq/dl) } & 4.20 & 4.33 & 5.00 & 7.28 & 6.78 & 5.67 & 0.36 \\
\hline \multicolumn{2}{|c|}{ Buff. Capac.(mg/dl) } & 7.49 & 7.72 & 6.91 & 7.41 & 7.51 & 7.84 & 0.29 \\
\hline
\end{tabular}


Abd El-Hady, M. A. A. et al.

Fig. (1): Showed rumen pH value and eNDF\% as affected by interaction between wilting and sampling time $(1=0 \mathrm{hr} ; 2=2 \mathrm{hr} ; 3=4 \mathrm{hr}$ and 4= $8 \mathrm{hr}$ after feeding).

Fig. (2): Showed rumen NH3-N and TVFA's concentrations as affected by interaction between wilting and sampling time (1=0 hr; 2= $2 \mathrm{hr}$ and $3=4 \mathrm{hr}$ after feeding).

The obtained results are in accordance with those of Abou El-Enin (2005) who used different additives during ensiling berseem included formic acid. Similar values of rumen $\mathrm{pH}, \mathrm{eNDF}, \mathrm{NH}_{3}-\mathrm{N}$ and TVFA's were found by Sharaf (2008), when he ensiled corn stover as a whole plant or without ears with different additives. In accordance with the present study, Jatkauskas and Vrotniakiene (2006) proposed that red clover silage treated with formic acid did not affect significantly rumen $\mathrm{pH}$, TVFA's and $\mathrm{NH}_{3}-\mathrm{N}$ values. Despite a substantial difference in silage $\mathrm{pH}$, the rumen $\mathrm{pH}$ (on average 6.94) was not affected by the diet, probably due to the buffering capacity of saliva. In general, the levels of rumen $\mathrm{pH}$ recommendation ranges for high proteolytic (pH 6-7) and cellulolytic ( $\mathrm{pH}$ 6.2- 6.8) activities (Hassen et al., 2009). Contrary findings were reported by Baytok et al. (2005) who found that rumen $\mathrm{NH}_{3}-\mathrm{N}$ decreased $(\mathrm{P}<0.05)$ significantly by formic acid treatment of corn silage. The rumen $\mathrm{NH}_{3}$ values recorded for rams fed berseem silages at all sampling times in excess of $5 \mathrm{mg} / \mathrm{dl}$, which has been reported to maximize microbial protein synthesis (Woolford, 1984). According to Satter and Roffler (1975) values of $\mathrm{NH}_{3}-\mathrm{N}$ lower than $2.5-5 \mathrm{mg} / \mathrm{dl}$ rumen fluid may inhibit 
rumen activity, while Ǿrskov (1982) suggested a rumen $\mathrm{NH}_{3}-\mathrm{N}$ concentration of $20-24 \mathrm{mg} / \mathrm{dl}$ for maximum fermentation rate. Deswaysen (1980) reported that in un-chopped silage the fermentation of a mat of interwoven particle in the rumen delays the separation and backflow of small particles into the reticulum and, as well as, ruminations delayed. Since the rate of particle reduction of un-chopped silage is slower than that of chopped material, the reticulo-rumen retention time of digesta is longer, that explain the lower $\mathrm{pH}$, greater TVFA's and consequently higher digestibility of chopped and treated silage.

\section{Blood metabolites:}

Data in Table (8) presents blood hematological and metabolites of experimental rams as affected by wilted, formic, fasting time and interaction among them. The hemoglobin $(\mathrm{Hb})$ concentration and hematocrit\% $(\mathrm{HT})$ were higher $(P<0.01)$ significantly in wilting groups than un-wilting. Whereas, red blood cell counts $(R B C ' s)$ was greater $(P<0.01)$ in un-wilting group than others, as well as white blood cell counts (WBC's) was tend to be higher in unwitting group than others but without significant differences among groups. On the other side, formic acid treatment did not affect significantly on any hematological criteria. Plasma total protein and glucose concentrations were higher $(P<0.01)$ significantly in wilting groups than un-wilting. The highest value of $T$. protein and glucose was in second group which wilted for $24 \mathrm{hr}$ (being 7.76 and $46.8 \mathrm{mg} / \mathrm{dl}$, respectively). Whereas, T. protein and glucose did not differ significantly by formic acid treatment. The interaction between wilting and formic did not affect plasma glucose levels, but tend to be effective $(P=0.05)$ with $T$. protein (Fig 3).

Table (8): Blood metabolites of experimental rams as affected by wilting with or without formic acid treatments of berseem silage rations before and after feeding.

\begin{tabular}{|c|c|c|c|c|c|c|c|c|c|c|}
\hline \multirow{3}{*}{ Items } & \multicolumn{10}{|c|}{ Chopped Silage } \\
\hline & \multicolumn{4}{|c|}{ Wilting (hr) } & \multicolumn{3}{|c|}{ Formic } & \multicolumn{3}{|c|}{ Significance } \\
\hline & 0 & 24 & 48 & SE & $-F$ & $+\mathbf{F}$ & SE & Wilt. & Form & WxF \\
\hline $\mathrm{Hb}$ & $10.5^{b}$ & $11.3^{\mathrm{a}}$ & $11.3^{a}$ & 0.13 & 11.2 & 10.9 & 0.10 & $\star \star *$ & NS & NS \\
\hline HT & $31.6^{b}$ & $34.4^{\mathrm{a}}$ & $34.7^{a}$ & 0.49 & 33.8 & 33.4 & 0.39 & $\star \star$ & NS & NS \\
\hline RBC's & $4.51^{a}$ & $3.90^{\mathrm{b}}$ & $3.86^{b}$ & 0.09 & 4.05 & 4.13 & 0.074 & ** & NS & NS \\
\hline WBC's & 5.28 & 4.92 & 4.95 & 0.39 & 5.21 & 4.88 & 0.32 & NS & NS & NS \\
\hline T. protein & $6.56^{b}$ & $7.76^{\mathrm{a}}$ & $7.39^{a}$ & 0.17 & 7.14 & 7.32 & 0.14 & $\star \star$ & NS & NS \\
\hline Glucose & $39.2^{b}$ & $46.8^{a}$ & $44.6^{a}$ & 1.65 & 42.1 & 45.0 & 1.35 & ** & NS & NS \\
\hline AST & 78.2 & 79.4 & 84.8 & 2.95 & 81.9 & 79.7 & 2.41 & NS & NS & NS \\
\hline Createnine & $1.10^{\mathrm{a}}$ & $0.82^{b}$ & $1.04^{\mathrm{a}}$ & 0.04 & 1.03 & 0.94 & 0.03 & ** & NS & * \\
\hline
\end{tabular}

a and b lest square means in the same row for chopped silage with different superscript differ significantly $(P<0.01)$

${ }^{\star} \mathrm{P}<0.05 ;{ }^{* *} \mathrm{P}<0.01 ; \mathrm{NS}=$ non-significant

Plasma aspartate aminotransferase (AST) was not affected significantly by main factors. Whereas, plasma createnine was affected $(P<0.01)$ significantly by wilting for $24 \mathrm{hr}$ and the interaction $(P<0.05)$ between wilting and formic (Fig 3). Createnine levels ranged from 0.82 to 
$1.10 \mathrm{mg} / \mathrm{dl}$ and were within the normal level of sheep. The results of blood metabolites are in the normal range according to Mohamed and Selim (1999) and indicated that all animals were in a good nutritional status. Data are in coincidence with the findings of Eid (1998); Allam et al. (1997) and El Shaer et al. (2001). There were no adverse effect on kidney and liver function as well as blood hematology ( $\mathrm{Hb}, \mathrm{HT}$ and WBC's), this indicated that the animals were in a good health as a result of inclusion of a good fermented berseem silage.
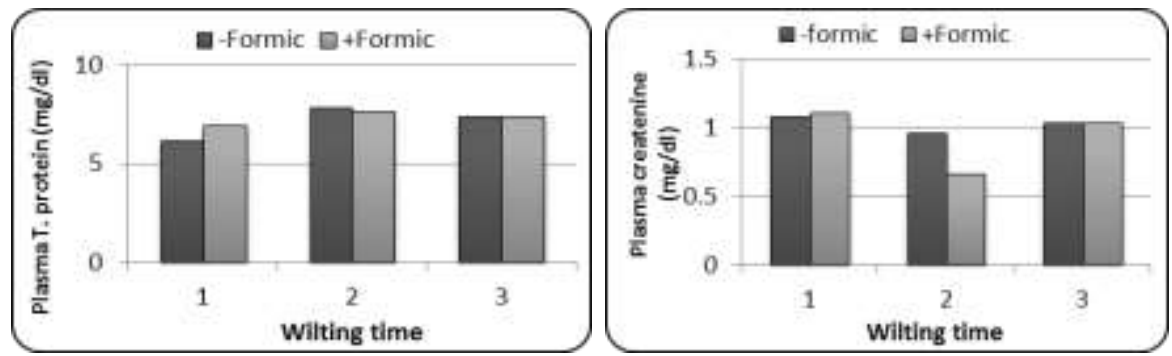

Fig. (3): Plasma T. protein and createnine levels of rams as affected by wilting $x$ Formic interaction (1=0 hr; $2=24 \mathrm{hr}$ and $3=48 \mathrm{hr}$ wilting time).

\section{Conclusion:}

It could be concluded that, the lowest quality and digestibility was in un-chopped silage with or without formic acid treatment. Chopping and wilting berseem forage for $24 \mathrm{hr}$ (about 20\% DM) as pre-ensiled treatments with $0.5 \%$ formic acid sprinkle produced the best quality silage and higher digestibility without any side effect on health of rams, which could be resulted in improvement growth performance of the animal.

\section{REFERENCES}

A.O.A.C. (1990). Association of Official Analytical Chemists Methods of Analysis. $16^{\text {th }}$ ed. Washington, D.C., USA.

Abou EL-Enin,Ebtehag I.M. (2005). Nutritional evaluation of different treatments in silage production for ruminants feeding. $\mathrm{PhD}$ Thesis Ain Shams University.

Allam, S.M.; Hanfy, M.A.; Goma, I.A. and Abdou, A.M. (1997). Effect of ammoniation on date seeds utilisation in dairy rations. In: Proceeding of the 6th Conference on Animal Nutrition, El Minia (Egypt), 17-19 November 1997.

Aksu, E.B.T.; Karsli, M.A. and Muruz, H. (2005). The effects of formic acid, molasses and inoculant as silage additives on corn silage composition and ruminal fermentation characteristics in sheep. Turk $\mathrm{J}$ Vet Anim Sci. 29: 469-474. 
Barker, S. B. and Summerson. W. H. (1941). The colorimetric determination of lactic acid in biological material. J. Biol. Chem. 137: 537-554.

Barry, T.N.; Cook, J.E. and Wilkins, R.J. (1978). Journal of Agricultural Science, Cambrige, 91:701-715. C.F. McDonald et al. (1991).

Baytok, E.; Aksu, T.; Karsli, M.A. and Muruz, H. (2005). The Effects of Formic Acid, Molasses and Inoculant as Silage Additives on Corn Silage Composition and Ruminal Fermentation Characteristics in Sheep. Turk J Vet Anim. Sci., 29: 469-474.

Bolsen, K.K.; Ashbell, G. and Weinberg, Z.G. (1996). Silage fermentation and silage additives: Review. Asian-Aust. J. Anim. Sci. 9:483-489.

Cai, Y.; Benno, Y.; Ogawa, M.; Ohmomo, S.; Kumal, S. and Nakase, T. (1998). Influence of Lactobacillus spp. From an inoculant and of Weissellaand Leuconostocspp. From forage crops on silage fermentation. Appl. Environ. Microbiol., 64 (8) 2982-2987.

Calsamiglia, S.; Stern, M.D. and Firkins, J.L. (1995). Effects of protein source on nitrogen metabolism in continuous culture and intestinal digestion In Vitro. J. Anim. Sci., 73: 1819.

Carpintero, M. C.; Holding, A. J. and McDonald, P. (1969). Fermentation studies on lucerne. J. Sci. of food and Agriculture, 20:677-681.

Conway, E.F. (1957). Micro-diffusion analysis and Volumetric Error. Rev. Ed. Lock wood, London.

Dawson, L.E.R.; Ferris, C.P.; Steen, R.W.J.; Gordon, F.J. and Kilpatrick, D.J. (1998). The effects of wilting grass prior to ensiling on silage intake. Grass and Forage Sci., submitted.

Deswaysen, A.G. (1980). Proceeding of the British Grassland Society Occasional Symposium No. 11, Brighton 345-349.

Donaldson, E. and Edwards, R.A. (1976). Feeding value of silage: Silages made from freshly cut grass, wilted grass and formic acid treated wilted grass. J. The Science of food and Agriculture, 27:536-544.

Duncan, D.B. (1955). Multiple range and multiple F tests. Biometrics, 11: 1.

Eid, E.Y. (1998). Effects of organic wastes utilization in ruminant feeding on animal performance under desert conditions. MSc Thesis, Faculty of Agriculture, Zagazig University, Egypt.

El-Shaer H.M., Fahmy, A.A.; Abdul Aziz, G.M Shalaby, A.S. and Abd ElGawad, A.M. (2001). Nutritional evaluation of non- conventional fattening diets fed to sheep under arid conditions of Egypt. Proceeding of International Conference, Tunisia, 8- 10 Nov.

Etman, K.E.I.; Mostafa, M.R.M; El-Sayes, M.F. and Gaafar, E.M. (1995). Nutritional studies on silage made from Egyptian clover with or without additives. Egypt J. Appl. Sci., 10 (8):264-273.

Fairbairn, R.L.; Alli, I. and Phillip, L.E. (1992). Proteolysis and amino acid degredation during ensiling of untreated or formic acid-treated Lucerne and maize. Grass Forage Sci., 47:382-390.

Flieg, O. (1952). The question of the evaluation of silage. Landwirtschaftlicheforschung, 3: 169-176. 
Fox, D.G.; Tylutki, T.P.; Van Amburgh, M.E.; Chase, L.E.; Pell, A.N.; Overton, T.R.; Tedeschi, L.O.; Rasmussen, C.N. and Durbal, V.M. (2000). The net carbohydrate and protein system for evaluating herd nutrition and nutrient excretion. Anim. Sci. Mimeo 213, Dpt. Anim. Sci., Cornell Univ., 130 Morrison Hall, Ithaca, New york 14853.

Fransen, S.C. and Strubi, F.J. (1998). Relationships among absorbents on the reduction of grass silage effluent and silage quality. J. Dairy Sci. 81: 2623.

Gary, M. (1992). Ensiling Process. In: Silage Manual (Ed. M. Bjorge and H. Bjorge). Edmonton, Alberta. pp. 14-17.

Gibson, T.; Stirling, A.C.; Keddie, R.M. and Rosenberger, R. F. (1958). Bacteriological changes in silage made at controlled temperatures. $\mathrm{J}$. gen. Microbiol. 19, 112-129.

Gordon, F.J.; Dawson, L.E.R.; Ferris, C.P.; Steen, R.W.J. and Kilpatrick, D.J.(1999).The influence of wilting and forage additive type on the energy utilization of grass silage by growing cattle. Anim. Feed Sci. and Tech., 79:15-27.

Haigh, P.M.(1988). The effect of wilting and silage additives on the fermentation of autumn made grass silage ensiled in bunkers on commercial farms in south wales. Grass Forage Sci., 43:337-345.

Haigh, P.M. and Mansbridge, R.J. (1998). The Effect of Formic Acid with Formalin on Grass Silage Fermentation and the Performance of Dairy Cows. 69:255-259.

Hassen, A.; Van Niekerk, W.A. and Bechaz, F.M. (2009).Silage fermentation attributes and certain rumen parameters in sheep fed two grass silages harvested at different stages of maturity. South African Journal of Animal Science. 39 (1):229-233.

Handerson, A.R.; McDonald, P. and Anderson, D.H. (1982). The effect of silage additives containing formaldehyde on the fermentation of ryegrass ensiled at different dry matter levels and on nutritive value of direct cut silage. Animal Feed Science and Technology. 7:303-314.

Henderson, A.R, McDonald, P. and Woolford, M.K.(1972).Chemical changes and losses during the ensilage of wilted grass treated with formic acid. J. Sci. Food. Agr., 23: 1079-1087.

Jasaitis, D.K.; Wohlt, J.E. and Evans, J.I. (1987). Influence of fed ion content on buffering capacity of ruminant feedstuffs in vitro. J. Dairy Sci., 70:1391.

Jatkauskas, J. and Vrotniakiene, V. (2006). Effects of silage fermentation quality on ruminalfluid parameters. BIOLOGIJA. 2006. Nr. 4. P. 65-71.

Jayaprakasha, G.K. and Sakariah, K.K. (2002). Determination of organic acids in leaves and rinds of Garciniaindica (Desr.) by L.C. Journal of Pharmaceutical and Biomedical analysis. 28:379-384.

Khan, M. A.; Sarwar, M.; Nisa, M. ; Khan, M. S.; Iqbal, Z.; Lee, W. S.; Lee, H. J. and Kim, H.S. (2006). Chemical composition, in situ digestion kinetics and feeding value of Oat grass (Avena sativa) ensiled with molasses for Nili-Ravi Buffaloes. Asian-Aust. J. Anim. Sci. 19:11271133. 
Kokkonen, T.; Tuori, M; Leivonen, V. and Syrjala-Qvist, L. (2000). Effect of silage dry matter content and rapeseed meal supplementation on dairy cows. Animal Feed Sci. and Tech., 84:213-228.

Matsuoka, S., Yonezawa, S.; Ishitabi, H.; Osanai, K. and Fujita, H. (1993). The effect of moisture content on aerobic deterioration of grass silage. Proc. World Conf. Anim. Prod. Edmonton, Canada. pp. 100-101.

Mayne, C.S. and Steen, R.W.J. (1990). Recent research in silage additives for milk and beef production. Sixty-third Annual Report of the Agric. Res. Inst. Of Northern Irland, pp. 31-42.

McDonald, P. (1981). The biochemistry of silage. John Wiley and Sons, New York, NY.

McDonald, P.; Henderson, A.R. and Ralton, I. (1973).Energy changes during ensilage Journal of the Science of feed and Agriculture. 24:827-834.

McDonald, P; Henderson, N. and Heron, S. (1991). The biochemistry of silage. $\left(2^{\text {nd }}\right.$ Ed.), Aberystwyth, UK, Chalcombe Publications.

Mohamed, H.A. and Selim, H.M. (1999). Hand book of Veterinary internal Medicine. Dpt. Anim. Medicine, Faculty of Vet. Medicine, Zagazig Univ.

Moore, J.E. (1994). Forage quality indices: development and application. P. 977-998.

Moore, J.E. and Kunkle, W.E. (1995). Improving forage supplementation programs for beef cattle. Pp. 65-74. In $6^{\text {th }}$ Annual Florida Rumination Symposium.

Mustafa, A.F. and Seguin, P. (2003). Ensiling characteristics, ruminal nutrient degradabilities and whole tract nutrient utilization of berseem clover (Trifoliumalexandrinum L.) silage. Canadian J. Anim. Sci., 147-152.

National Research Council (2001). Nutrient requirements of dairy cattle, seventh Revised Edition. National Academy Press, Washington, D.C.

National Research Council (NRC) (1985). Nutrition requirements of sheep. $6^{\text {th }}$ revised Ed. National Academy Press. Washington. D.C.

Ørskov, E.R., (1982). Protein Nutrition in Ruminants. Academic Press, New York.

Polan, C.E., Stieve, D.E. and Garrett, J.L. (1998). Protein preservation and ruminal degradation of ensiled forage treated with heat, formic acid, ammonia, or microbial inoculant. J. Dairy Sci., 81: 765-776.

Rees, D.V.H.; Audsley, E. and Neale, M.A. (1983). J. Agric. Sci. Cambridge. 100:601-605. C.F. McDonald et al. (1991).

Rohr, K. and Thomas, C. (1984). Intake, digestibility and animal performance. In: 'Efficiency of Silage Systems: A Comparison Between Unwilted and Wilted Silages' (ed. E. Zimmer and R.J. Wilkins), LandbauforschungVolkenrode, Sonderheft69:64-70.

Rowghani, E.and Zamiri, M. J. (2009). The effects of a microbial inoculant and formic acid as silage additives on chemical composition, ruminal degradability and nutrient digestibility of corn silage in sheep. Iranian $\mathrm{J}$. Vet. Res., Shiraz Univ., 10(2):110-118.

Ruxton, I.B. (1972). M.Sc. Thesis, University of Edinburgh. C.F. Woolford, M.K. (1983). 
Sarwar, M.; Khan, M.A.; Nisa, M. and Touqir, N.A. (2005). Influence of berseem and lucerne silages on feed intake, nutrient digestibility and milk yield in lactating Nili buffaloes. Asian-Aust. J. Anim. Sci. 18:475478.

SAS (2004). SAS User's Guide, SAS (Statistical Analysis System) Institute, Cary, NC.

Satter, L. D., and Roffler, R. E. (1975). Nitrogen requirement and utilization in dairy cattle. J. Dairy Sci. 58:1219.

Shalaby, A. S.; Abdel-Aziz, G.M.; Rammah, A.M. and Beshay, M.G. (1989). Fodder beet, a new forage in Egypt. 2- Nutritional evaluation of fresh fodder beet (beta Vulgaris L.) and its silage with or without roughages. The $3^{\text {rd }}$ Egyptian-British Conf. On Animal., Fish and Poultry Production, 7-10 Oct., Alex. Univ., Egypt.

Sharaf, K.M.I. (2008). Studies on the use of silage in animal feeding. M.Sc. Thesis, Mans. Univ.

Shaver, R.D.; Bytes, A.J.; Satter, L.D. and Jorgensen, N.A. (1986). Influence of amount of feed intake and forage physical form on digestion and passage of pre-bloom alfalfa hay in dairy cows. J.Dairy Sci. 69: 1545.

Schneider, B. H. and Flatt, W. P. (1975). The evaluation of feeds though digestibility experiments. The University of Georgia press Athens, 3: 602.

Shrestha, S. A., Hesterman, O. B., Squire, J. M., Fisk, J. W. and Sheaffer, C. C. (1998). Annual medics and berseem clover as emergency forages. Agron. J. 90: 197-201.

Snyman, L.D., Joubert, H.W. (1996). Effect of maturity stage and method of preservation on the yield and quality of forage sorghum. Anim. Feed Sci. Techn., 57: 63-73.

Suepea, S.; ChiHsin, L.; WenWei, K.; RueyHshiung, B. and JengBin, L. (2000). Forage production and silage making for berseem clover. J. Taiwan Livestock Research, 33:105-110.

Tauqir, N.A.; Nisa, M.; Sarwar, M. and Bhatti, S.A. (2008). Impact of varying moisture levels, different additives and fermentation periods on nutritive value of leguminous and non-leguminous fodder silages in lactating niliravi buffaloes. Pak. J. Agric., 45:386-402.

Thomas, C. and Thomas, P.C. (1985). Factors affecting the nutritive value of grass silages. p. 223-256, in: D.J. Cole \& W. Haresign (eds) Recent Advances in Animal Nutrition. London: Butterworths.

TouqirN. A.; Khan, M.A.; Sarwar, M.; Nisa, M.; Lee, W. S.; Lee, H. J. and Kim, H. S. (2007). Influence of Varying Dry Matter and Molasses Levels on Berseem and Lucerne Silage Characteristics and Their In situ Digestion Kinetics in Nili Buffalo Bulls. Asian-Aust. J. Anim. Sci. Vol. 20, No. $6: 887-893$.

Van Keulen, J. and Young, P.A. (1977). Evaluation of acid insoluble ash as a natural marker in ruminantdigestibility studies. Journal of Animal Science, 44: 282-287.

Van Soest, P.J.; Robertson, H.B. and Lewwis, B.A. (1991). Method of dietary fiber and non-starch polysaccharides in relation to animal material. $\mathrm{J}$. Dairy Sci. 74: 3583. 
Waldo, D.R. and Schultz, L.H. (1956). Lactic acid production in the rumen. J. Dairy Sci., 39:1455.

Warner, A.C.I. (1964). Production of volatile fatty acids in the rumen, methods of measurements. Nutr. Abst. \&Rev., 34:339.

Weinberg, Z.G. and Ashbell, G. (2003). Engineering aspects of ensiling. Biochemical Engineering Journal 13: 181-188.

Wilkins, R. J. (1984). A review of the effects of wilting on the composition and feeding values of silage. In: E. Zimmer and R. J. Wilkins (Ed.). Efficiency of silage systems: a Comparison Between Wilted and Unwilted Silages. LandbauforschungVolkenrode, Sonderheft 69:71-72.

Woolford, M.K. (1984). The Silage Fermentation. Marcel Dekker, New York, USA.

Yan, T.; Patterson, D.C.; Gordon, F.J. and Kilpatrick, D.J. (1998). Effects of bacterial inoculation of unwilted and wilted grass silages. 1. Rumen microbial activity, silage nutrient degradability and digestibility. J. Agric. Sci., Cambridge, 131:103-112.

Yan, T.; Patterson, D.C.; Gordon, F.J. and Porter, M.G. (1996). The effects of wilting of grass prior to ensiling on the response to bacterial inoculation 1. Silage fermentation and nutrient utilization over three harvests. Anim. Sci., 62:405-417.

Zhang, J. (2011).Effects of chopping length and cellulase addition on ensiling of guinea grass (Panicum maximum Jacq.). Grassland Sci., 57: 113115.

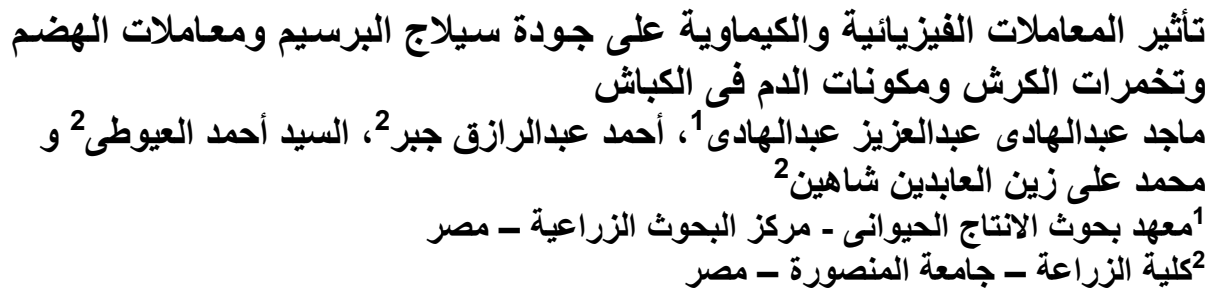

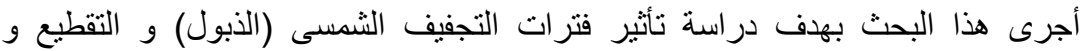

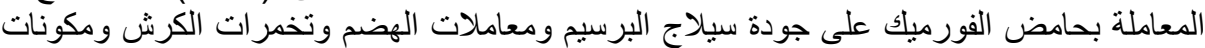

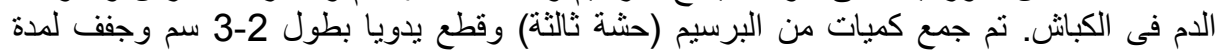

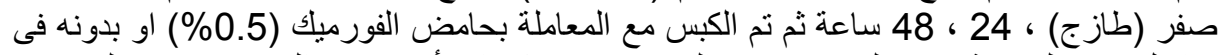

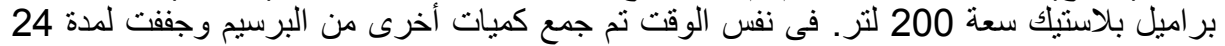

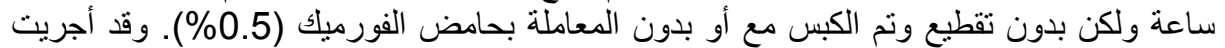

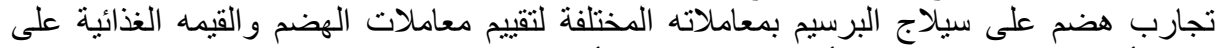

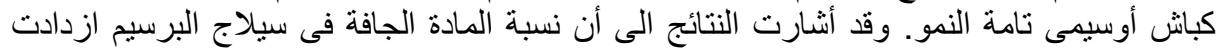

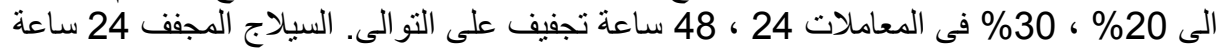

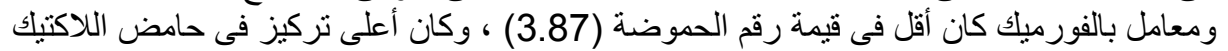

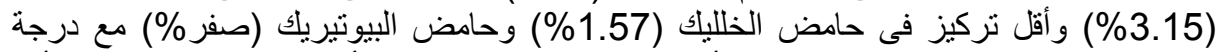

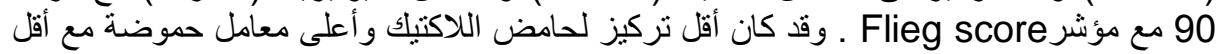
درجة من مؤشر Flieg score للجودة كان مع سيلاج البرسيم الغير مقطع سو اء المعامل بالفورميك 
أو بدون معاملة. كذلك كان أعلى عدد من بكتيريا حامض اللاكتيك و أقل عدد من بكتيريا الكلوستريديا

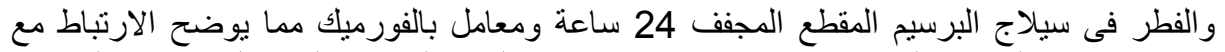

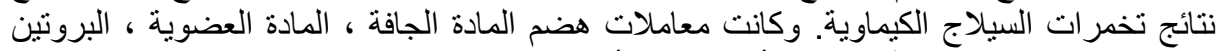

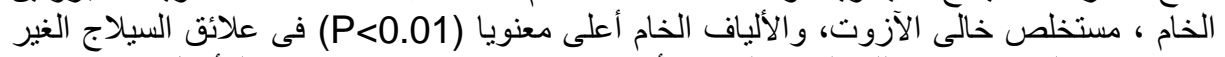

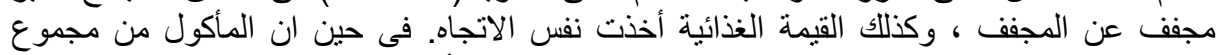

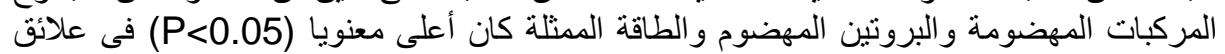

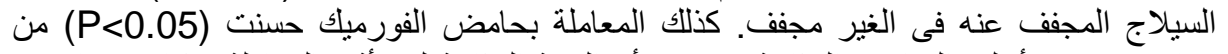

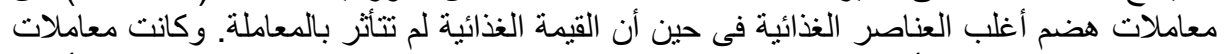

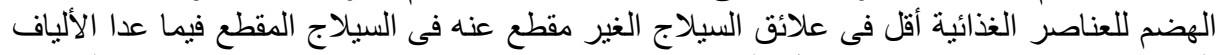

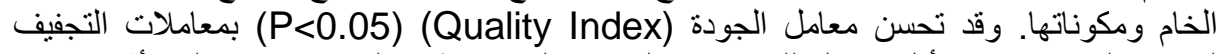

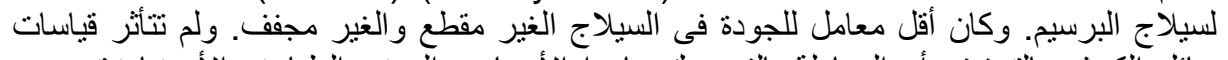

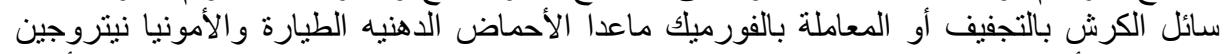

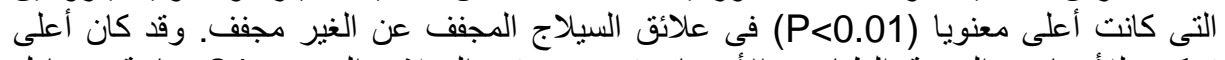

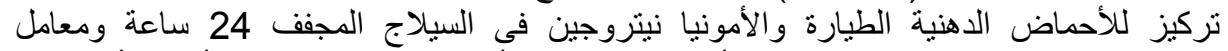

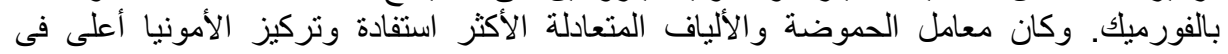

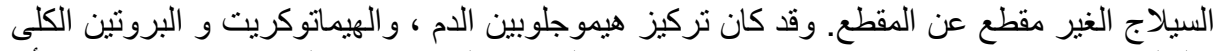

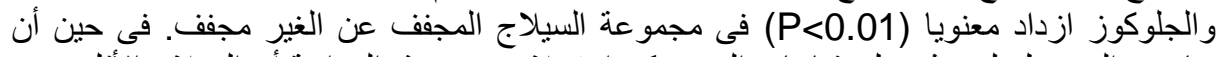

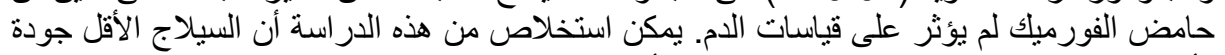

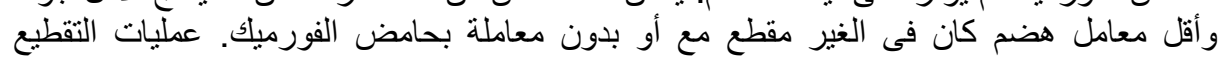

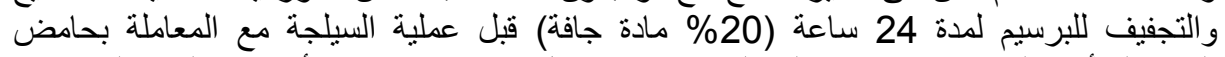

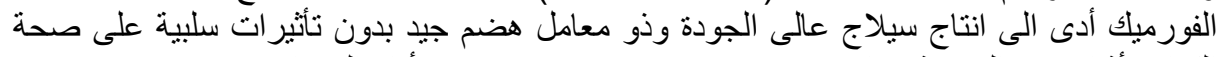

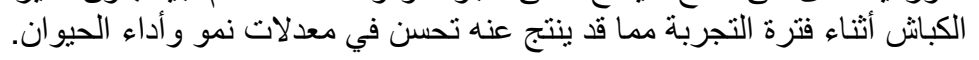

\author{
كلية الزراعة - جامعة المنصورة \\ مركز البحوث الزراعية
}

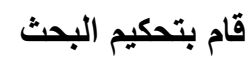 \\ أ.د / محمود يوسف البحث العايق \\ أ.د / هدى محمد الحسينى العايث
}


J. Animal and Poultry Prod., Mansoura Univ., Vol.3 (6), june, 2012 